\title{
DESKRIPSI PEDAGOGICAL CONTENT KNOWLEDGE GURU MATEMATIKA DITINJAU DARI PERBEDAAN GENDER
}

\author{
Putri Nur Diana ${ }^{1}$, Helti Lygia Mampouw ${ }^{2}$ \\ 1,2 Program Studi Pendidikan Matematika, Universitas Kristen Satya Wacana Salatiga \\ Jl. Diponegoro No.52-60, Salatiga, Sidorejo \\ 202015048@student.uksw.edu
}

\begin{abstract}
The differences of gender can be affect the ability pedagogical content knowledge of mathematics teachers. The purpose of this study is to find out the mathematics teacher's pedagogical content knowledge by gender. This type of research is qualitative descriptive. The subject consisted of one female teacher and one male teacher. Data collection techniques used in this study were observation, interviews, and documentation. Data analysis techniques used are data reduction, data presentation, and drawing conclusions or verification. The results of this study indicate that according to the two teachers have carried out mathematics learning well, have implemented existing learning models for students, have carried out assessments in accordance with aspects of the 2013 curriculum assessment. Both teachers lack the use of teaching aids during mathematics learning. Female teachers are more active during learning than male teachers. Female teachers are more aware of the material contained in the 2013 curriculum. For the whole, mathematics teacher's pedagogical content knowledge looks superior to female teachers compared to male teachers.
\end{abstract}

Keywords: Pedagogical Content Knowledge, Gender

\begin{abstract}
Abstrak
Perbedaan gender dapat berpengaruh pada kemampuan pedagogical content knowledge guru matematika. Tujuan dari penelitian ini adalah untuk mengetahui pedagogical content knowledge guru matematika berdasarkan gender. Jenis penelitian ini adalah deskriptif kualitatif. Subjek terdiri dari satu guru perempuan dan satu guru laki-laki. Teknik pengumpulan data yang digunakan dalam penelitian ini yaitu observasi, wawancara, dan dokumentasi. Teknik analisis data yang digunakan yaitu reduksi data, penyajian data, dan menarik kesimpulan atau verifikasi. Hasil penelitian ini menunjukkan bahwa menurut kedua guru sudah melaksanakan pembelajaran matematika dengan baik, sudah menerapkan model-model pembelajaran yang ada untuk peserta didik, sudah melakukan penilaian sesuai dengan aspek penilaian kurikulum 2013. Kedua guru kurang dalam penggunaan alat peraga saat pembelajaaran matematika. Guru perempuan lebih aktif pada saat pelaksanaan pembelajaran dibandingkan dengan guru laki-laki. Guru perempuan lebih paham mengenai materi yang ada dalam kurikulum 2013. Untuk keseluruhan, pedagogical content knowledge guru matematika terlihat lebih unggul guru perempuan dibandingkan dengan guru laki-laki.
\end{abstract}

Kata Kunci: Pedagogical Content Knowledge, Gender

Peraturan Pemerintah Republik Indonesia (PPRI) nomor 19 tahun 2017 tentang perubahan atas peraturan pemerintah nomor 74 tahun 2008 tentang guru ketentuan pasal 1 yang menegaskan bahwa guru adalah pendidik profesional dengan tugas utama mendidik, mengajar, membimbing, mengarahkan, melatih, menilai, dan mengevaluasi peserta didik pada pendidikan anak usia dini jalur pendidikan formal, pendidikan dasar, dan pendidikan menengah. Guru memiliki peran penting, merupakan posisi strategis, dan bertanggung jawab dalam pendidikan nasional (Rudiawan, 2009). Selain itu, guru juga sebagai fasilitator untuk mewujudkan kegiatan pembelajaran yang diharapkan.

Pedagogical Content Knowledge (PCK) menurut Shulman (1987) adalah suatu jenis pengetahuan seorang guru yang didasarkan pada cara guru mengaitkan pengetahuan pedagogik (pengetahuan 
tentang cara mengajar) dengan pengetahuan konten (pengetahuan tentang materi ajar). PCK merupakan kemampuan seorang guru untuk menguasai materi yang akan diajarkan dan menguasai pengetahuan tentang mengajar peserta didik. Komponen dalam Pedagogical Content Knowledge (PCK) yaitu pemahaman materi ajar (content knowledge) dan pemahaman cara mendidik (pedagogical knowledge).

Hubungan antara pemahaman materi ajar (content knowledge) dan pemahaman cara mendidik (pedagogical knowledge) dapat digambarkan melalui diagram berikut:

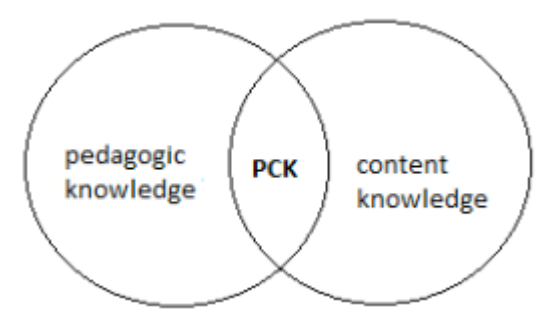

Gambar 1. Hubungan antara content knowledge dan pedagogical knowledge

Sumber: Mampouw (2011)

Pada Gambar 1 terlihat bahwa Pedagogical Content Knowledge (PCK) merupakan irisan dari pedagogical konwledge dan content knowledge. Dalam PCK kompetensi pedagogik dan kompetensi profesional sudah menjadi suatu kesatuan yang saling melengkapi satu dengan lainnya.

Terdapat beberapa penelitian yang telah meneliti tentang PCK antara lain: 1) Penelitian Apriliyanti (2016) dalam PCK guru SMP pada materi Perbandingan. Hasil penelitian Apriliyani menunjukkan bahwa masing-masing guru telah berusaha melaksanakan tugas mengajarnya dengan baik, memiliki pemahaman yang baik tentang materi perbandingan, mampu menjelaskan aplikasi materi perbandingan dalam kehidupan sehari-hari serta mampu memahami tujuan dari penyampaian materi perbandingan. Kompetensi profesional yang bisa dikatakan cukup baik ini ternyata tidak sejalan dengan prestasi belajar siswa tentang materi perbandingan. Kompetensi pedagogik yang masih belum dikuasai guru adalah penguasaan proses pembelajaran. 2) Penelitian Windarto (2016) dalam PCK guru pada materi Aljabar kelas VII di SMP kecamatan Bringin. Hasil penelitan Windarto menunjukkan bahwa dari sisi pedagogik, guru telah melakukan pembelajaran melalui metode-metode yang disesuaikan dengan kemampuan peserta didik dan bisa membuat peserta didik lebih tertarik dan antusias dalam pembelajaran Aljabar.

Pedagogical knowledge berkaitan dengan cara dan proses mengajar yang meliputi pengetahuan tentang manajemen kelas, tugas, perencanaan pembelajaran dan pembelajaran peserta didik menurut Shulman (1986). Kompetensi pedagogik guru menurut PPRI No.74 tahun 2008, merupakan kemampuan guru dalam pengelolaan pembelajaran peserta didik yang sekurang-kurangnya meliputi:
a. pemahaman wawasan atau landasan kependidikan;
b. pemahaman terhadap peserta didik;
c. pengembangan kurikulum atau silabus;
d. perancangan pembelajaran; 
e. pelaksanaan pembelajaran yang mendidik dan dialogis;

f. pemanfaatan teknologi pembelajaran;

g. evaluasi hasil belajar; dan

h. pengembangan peserta didik untuk mengaktualisasikan berbagai potensi yang dimilikinya.

Menurut Shulman (1986) content meliputi pengetahuan konsep, teori, ide, kerangka berpikir, metode pembuktian dan bukti. Kompetensi profesional guru menurut PPRI No.74 tahun 2008, merupakan kemampuan guru dalam menguasai pengetahuan bidang ilmu pengetahuan, teknologi, dan/atau seni dan budaya yang diampunya yang sekurang-kurangnya meliputi penguasaan:

a. materi pelajaran secara luas dan mendalam sesuai dengan standar isi program satuan pendidikan, mata pelajaran, dan/atau kelompok mata pelajaran yang akan diampu; dan

b. konsep dan metode disiplin keilmuan, teknologi, atau seni yang relevan, yang secara konseptual menaungi atau koheren dengan program satuan pendidikan, mata pelajaran, dan/atau kelompok mata pelajaran yang akan diampu.

Sebagai guru punya tanggungajawab yang sama, baik guru perempuan maupun guru laki-laki. Perbedaan gender semata-mata hanya bersifat sebagai penentuan.

Tujuan dari penelitian ini adalah mampu mendiskripsikan kemampuan PCK guru matematika berdasarkan gender. Gender adalah suatu konstruksi atau bentuk sosial yang sebenarnya bukan bawaan lahir sehingga dapat dibentuk atau diubah tergantung dari tempat, waktu/zaman, suku/ras/bangsa, budaya, status sosial, pemahaman agama, negara ideologi, politik, hukum, dan ekonomi (Nugroho, 2008). Dengan kata lain, gender bukanlah suatu kodrat dari Tuhan yang berupa perbedaan jenis kelamin yaitu laki-laki dan perempuan, melainkan buatan dari manusia yang dapat dipertukarkan dan memiliki sifat relatif. Sehingga gender merupakan perbedaan antara feminin dan maskulin.

Chandra (1983) mengatakan bahwa feminin adalah citra, sifat, ungkapan diri, yang bagaimanapun juga tetap didambakan oleh wanita, dan selalu ingin dipertahankannya. Sedangkan maskulin memiliki arti yang kasar dan jasmaniah, seperti jantan, lelaki, macho. Dapat disimpulkan bahwa feminim lebih cenderung ke perempuan, sedangkan untuk maskulin lebih cenderung ke lakilaki.

\section{METODE PENELITIAN}

Jenis penelitian yang digunakan adalah deskriptif kualitatif. Dikatakan kualitatif karena data berupa kalimat, gambar, dan bagan. Sedangkan penelitian deskriptif dilakukan dengan menggunakan variable sesuai dengan yang terjadi di lapangan yang biasa dijelaskan baik dengan kalimat maupun dengan angka.

Penelitian dilakukan di SMA Negeri kabupaten Grobogan. Subjek dalam penelitian ini adalah dua guru SMA Negeri di sekolah yang berbeda, sama-sama memiliki masa kerja yang setara, memiliki usia yang kurang lebih sama, satu guru laki-laki dan satu guru perempuan. PCK kedua 
subjek ditelusuri menggunakan PCK yang dikemukakan oleh Shulman (1986) menyebutkan terdapat

7 komponen PCK yang dapat diamati pada (tabel 1).

Tabel 1.

Komponen Pedagogical Content Knowledge (PCK)

\begin{tabular}{|c|c|c|}
\hline nen & Indikator & Contoh Pertanyaan \\
\hline $\begin{array}{l}\text { Pengetahuan } \mathrm{t} \\
\text { peserta didik }\end{array}$ & $\begin{array}{l}\text { Kemampuan guru } r \text { dalam } \\
\text { mengetahui tingkat } \\
\text { dan kemalitan } \\
\text { didik. } \\
\text { Kemampuan dasar peserta } \\
\text { mengetahui minat peserta didik. }\end{array}$ & $\begin{array}{l}\text { - Hambatan/kesulitan apa saja yang } \\
\text { terjadi pada peserta didik ketika } \\
\text { belajar mengenai turunan menurut } \\
\text { bapak/ibu? } \\
\text { - Dalam kemampuan belajar peserta } \\
\text { didik tersebut, apakah setiap } \\
\text { peserta didik memiliki kebutuhan } \\
\text { yang mendukung kemampuan } \\
\text { belajarnya? }\end{array}$ \\
\hline $\begin{array}{l}\text { Pengetahuan } \mathrm{t} \\
\text { kurikulum }\end{array}$ & $\begin{array}{l}\text { Kemampuan guru dalam } \\
\text { mengetahui standar kurikulum } \\
\text { yang berlaku saat ini. } \\
\text { - Kemampuan guru dalam } \\
\text { mendesain pembelajaran. }\end{array}$ & 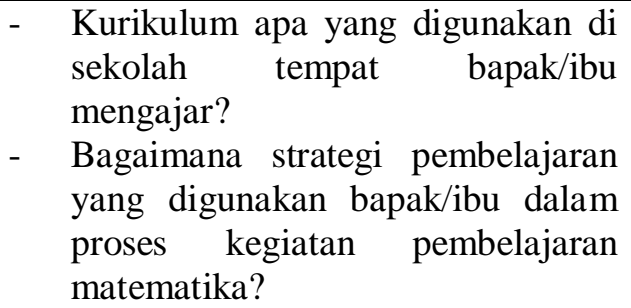 \\
\hline $\begin{array}{l}\text { Pengetahuan tentang } \\
\text { mengajar }\end{array}$ & \begin{tabular}{llr|} 
- & Kemampuan guru dalam \\
mengetahui cara-cara atau \\
metode-metode pembelajaran. \\
- \\
Kemampuan guru dalam \\
menghubungkan kemampuan \\
mengajar dengan metode \\
mengajar.
\end{tabular} & $\begin{array}{l}\text { - Model pembelajaran apa yang } \\
\text { bapak/ibu terapkan dalam proses } \\
\text { pembelajaran matematika? } \\
\text { Menurut bapak/ibu metode } \\
\text { pembelajaran apa yang tepat } \\
\text { dengan model pembelajaran } \\
\text { matematika? }\end{array}$ \\
\hline $\begin{array}{l}\text { Penget } \\
\text { tentang }\end{array}$ & $\begin{array}{l}\text { - Kempuan guru dalam tata cara } \\
\text { penilaian. } \\
\text { Kemampuan guru dalam } \\
\text { mengatasi hasil belajar peserta } \\
\text { didik yang belum mencapai } \\
\text { KKM. }\end{array}$ & 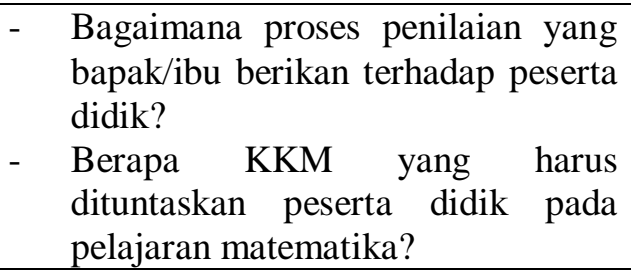 \\
\hline $\begin{array}{l}\text { Pengetahuan tentang } \\
\text { sumber daya }\end{array}$ & 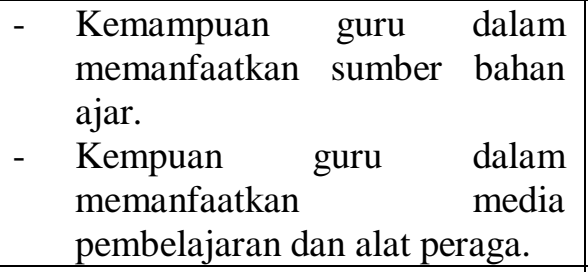 & $\begin{array}{l}\text { - Jika peserta didik belum } \\
\text { memahami materi yang bapak/ibu } \\
\text { sampaikan, lalu apa yang akan } \\
\text { bapak/ibu lakukan? } \\
\text { Apa saja media dan alat peraga } \\
\text { yang disediakan oleh sekolahan? }\end{array}$ \\
\hline $\begin{array}{l}\text { Pengetahuan } \\
\text { tentang content }\end{array}$ & $\begin{array}{l}\text { Kedalaman guru dalam } \\
\text { memahami materi. } \\
\text { - } \\
\text { Kemampuan guru menerapkan } \\
\text { materi. }\end{array}$ & $\begin{array}{l}\text { - Menurut bapak/ibu apakah setiap } \\
\text { ganti tahun ajaran materi } \\
\text { matematika ada yang berbeda? } \\
\text { - Apakah bapak/ibu memiliki } \\
\text { kendala ketika mengajarkan } \\
\text { matematika kepada peserta didik? }\end{array}$ \\
\hline $\begin{array}{l}\text { Pengetahuan tentang } \\
\text { tujuan }\end{array}$ & $\begin{array}{llr}\text { - } & \text { Kemampuan guru dalam } \\
\text { merumuskan tujuan. } \\
\text { - } \\
\text { Kemampuan guru dalam } \\
\text { menghubungkan materi dengan } \\
\text { aktivitas dalam kehidupan }\end{array}$ & $\begin{array}{ll}\text { - } & \text { Menurut bapak/ibu bagaimana cara } \\
\text { menyampaikan tujuan } & \text { tuad didik } \\
\text { pembelajaran kepada peserta did dapat } \\
\text { agar peserta didik } \\
\text { memahaminya? }\end{array}$ \\
\hline
\end{tabular}




\begin{tabular}{|l|l|l|}
\hline sehari-hari. & $-\begin{array}{l}\text { Saat pelaksanaan pembelajaran } \\
\text { apakah bapak/ibu menghubungkan } \\
\text { materi dalam kehidupan sehari- } \\
\text { hari? }\end{array}$ \\
\hline
\end{tabular}

Sumber: Shulman (1987), Anwar (2010), diolah

Teknik analisis data dari wawancara kedua subjek berdasarkan 7 komponen PCK, selanjutnya data diolah dan dinarasikan untuk dideskripsikan pada hasil dan pembahasan.

\section{HASIL DAN PEMBAHASAN}

\section{Komponen pengetahuan tentang peserta didik}

Kedua subjek memiliki pendapat yang sama terhadap minat belajar peserta didik yang kurang dalam pembelajaran matematika. Karena dasar pembelajaran peserta didik pada bidang matematika kurang menguasai, sehingga peserta didik merasa kesulitan belajar matematika pada jenjang sekolah yang lebih tinggi. Hal ini terlihat pada bukti wawancara kedua subjek dengan peneliti pada percakapan berikut:

[tersipu] gimana ini? Jawabnya saya gimana ini? kalau soal pakai angka saya mudah jawabnya mbak. Kalau seperti ini harus pintar ngomong. Siswa itu kurang

Guru P . aktif mbak. Apalagi kalau diminta untuk membaca LKS itu susah, padahal saya kalau mengajar ada LKS, ada catatan di papan tulis juga. Tapi anak-anak itu pasif kalau matematika, apalagi anak-anak IPS yang aktif paling satu kelas cuma 3 sampai 5 siswa aja.

Biasanya gini, mereka itu dasarnya waktu di SD maupun SMP pembelajarannya

Guru L : dalam proses matematika sepertinya kurang menguasai, sehingga di SMA nya itu kesulitan.

Ya harus dijelaskan lagi. Terpaksa harus mengulang pelajaran sewaktu SD,

Guru L : misalkan seperti dasarnya itu perkalian dan pembagian macam itu kan harusnya mereka sudah menguasai. Tapi nyatanya mereka harus mengulang kembali akhirnya ya dijelaskan kembali rumus-rumus dasarnya seperti itu.

Dalam pembelajaran matematika subjek P selalu menanyakan kepada peserta didik mengenai paham atau tidaknya materi yang sudah disampaiakan. Sedangkan subjek L harus mengulang kembali pelajaran sewaktu SD maupun SMP untuk mengingatkan peserta didik pada materi yang sudah pernah dipelajari sebelumnya. Kedua subjek menyatakan hal yang sama yaitu banyak peserta didik yang pasif saat pembelajaran matematika. Sehingga subjek memeberikan motivasi kepada peserta didik agar peserta didik dapat lebih bersemangat dalam pembelajaran matematika.

Hasil dari 2 subjek yang dimintai keterangan oleh peneliti, keduanya mengungkapkan hal yang sama, yaitu minat peserta didik kurang dalam pembelajaran matematika. Hasil penelitian ini berbeda dengan hasil penelitian Windarto (2016) dalam PCK guru pada materi Aljabar kelas VII di SMP kecamatan Bringin. Hasil penelitian Windarto menunjukkan bahwa semua responden memiliki 
jawaban yang sama untuk minat belajar peserta didik bahwa peserta didik antusias dan senang dalam pembelajaran. Untuk mengatasi permasalahan tersebut subjek mengungkapkan perlu adanya motivasi yang diberikan kepada peserta didik agar peserta didik bersemangat untuk mengikuti pembelajaran matematika. Diperoleh hasil yang sama mengenai pengetahuan tentang peserta didik antara guru perempuan dan guru laki-laki, menurut keduanya minat peserta didik kurang dalam pembelajaran matematika.

\section{Komponen Pengetahuan Tentang Kurikulum}

Kurikulum yang diterapkan pada sekolah dari kedua subjek adalah kurikulum 2013. Kedua subjek juga menyatakan lebih menguasai menggunakan KTSP daripada kurikulum 2013, karena menurut kedua subjek adanya kurikulum 2013 membuat guru kesulitan untuk menyampaiakan materi yang akan diajarkan. Hal ini terbukti pada hasil wawancara kedua subjek dengan peneliti pada percakapan berikut:

Kurikulum 2013 ini dari tahun ke tahun ada revisi terus mbak, malah enak pakai

Guru P : KTSP dulu. Menurut saya pakai KTSP lebih runtut materi-materinya, gak membingungkan seperti K13 ini [tertawa].

Sebenarnya KTSP lebih bagus menurut saya. Tapi dengan diganti K13 ini

Guru L : mayoritas bapak ibu guru juga mengalami kendala. Yang tadinya kita sudah

K13 siswa kayanknya kurang persiapan.

Kurikulum yang diterapkan pada sekolah dari kedua subjek adalah kurikulum 2013. Hal tersebut sudah diatur dalam Undang-Undang Nomor 32 Tahun 2013 tentang Sistem Pendidikan Nasional menyebutkan bahwa kurikulum adalah seperangkat rencana dan pengaturan mengenai tujuan, isi, dan bahan pelajaran serta cara yang digunakan sebagai pedoman penyelenggaraan kegiatan pembelajaran untuk mencapai tujuan pendidikan tertentu. Tetapi menurut pendapat kedua subjek, dapat diambil kesimpulan bahwa banyak guru termasuk subjek yang mengalami kesulitan untuk mengajar dengan menggunakan kurikulum 2013. Diperoleh hasil yang sama mengenai pengetahuan tentang kurikulum antara guru perempuan dan guru laki-laki, keduanya lebih menguasi jika mengajar menggunakan KTSP.

\section{Komponen Pengetahuan Mengajar}

Kedua subjek sama-sama menggunakan metode ceramah dan diskusi. Model yang digunakan subjek P biasanya adalah dengan cara mengelompokkan peserta didik. Sedangkan model pembelajaran yang digunakan subjek L yaitu jigsaw dan TGT. Subjek P melakukan hal tersebut karena untuk menyesuaikan kondisi kelas yang sedang berlangsung dalam pembelajaran matematika. Menurut subjek P jika kelas yang tempat subjek P mengajar tidak dapat diterapkan dengan modelmodel pembelajaran yang ada. Dengan demikian subjek P lebih aktif dalam kelas dengan berkeliling untuk melihat kemampuan peserta didik. Berbeda dengan subjek L yang mengulang kembali materi 
yang sudah disampaikan jika peserta didik belum paham dengan materi yang sudah diasampaikan. Hal ini terbukti pada hasil wawancara kedua subjek dengan peneliti pada percakapan berikut:

Kalau matematika pembelajarannya paling ya dikelompokkan mbak sama

Guru P : ceramah gitu. Kemarin padahal ya saya bikin kelompok itu ya pada gak bisa kok.

Guru L : Menyesuaikan materinya, biasanya pakai jigsaw, TGT seperti itu. Menyesuaikan materi aja.

Guru L $\quad$ : Ceramah dan diskusi mbak.

Kedua subjek sama-sama menggunakan metode pembelajaran ceramah dan diskusi. Model pembelajaran yang digunakan oleh kedua subjek berbeda, subjek P lebih sering mengelompokkan siswa (cooperative learning), sedangkan subjek L lebih sering menggunakan model pembelajaran jigsaw dan TGT. Hasil dari penelitian ini sama dengan hasil penelitian Windarto (2016) dalam PCK guru pada materi Aljabar kelas VII di SMP kecamatan Bringin. Hasil penelitian Windarto menunjukkan bahwa subjek memilih menggunakan metode kooperatif atau kelompok dan satu responden menggunakan tanya jawab dan tugas dalam pembelajaran Aljabar yang telah disesuaikan dengan kemampuan peserta didik. Subjek P lebih aktif dibandingkan dengan subjek L, yaitu dengan berkeliling untuk melihat kemampuan peserta didik dan membantu jika terdapat peserta didik yang mengalami kesulitan, sedangkan subjek L lebih sering untuk mengulang kembali materi yang sudah disampaikan. Terdapat perbedaan antara guru perempuan dan guru laki-laki. Guru perempuan lebih cenderung mengamati peserta didik secara individu untuk mengetahui letak kesulitannya dibandingkan dengan guru laki-laki.

\section{Komponen Pengetahuan Tentang Penilaian}

Pemberian nilai kedua subjek kepada peserta didik sama, kedua subjek bukan hanya menilai kemampuan belajar dan pengetahuan peserta didik. Tetapi kedua subjek juga melihat sikap peserta didik, seberapa jauh minat peserta didik untuk mau belajar matematika, serta keaktifan peserta didik. Hal ini terbukti pada hasil wawancara kedua subjek dengan peneliti pada percakapan berikut:

Kalau saya melihat muridnya dulu kalau ngasih nilai mbak. Kalau kelihatannya anaknya rajin biarpun gak terlalu paham ya nilainya agak bagus. Kalau anaknya pintar ya saya kasih bagus. Kalau orangnya bandel gak pernah mau nyatat ya saya kasih pas KKM. Jadi saya sesuaikan kondisi anak, tidak sembarangan. Makanya

Guru $P \quad$ : kalau saya jalan-jalan ke belakang nanti saya kasih tanda untuk anak-anak, biar kalau pas ngasih nilai nanti gak keliru. Kalau waktu bikin nilai di absen kok ada tanda plus berarti nanti nilainya saya tambahi, kalau di absen ada tanda min berarti nanti nilainya pas KKM gitu mbak. Soalnya kalau gak tuntas di rapor itu susah mbak. 
Guru L : Ada tugas, ulangan harian gitu mbak.

Guru L : Iya dinilai kalau mau maju ke depan mbak.

Nilai KKM matematika tempat kedua subjek mengajar berbeda. Untuk subjek P dari kelas X, XI, dan XII yaitu 70, 71, dan 72. Sedangkan untuk subjek L dari kelas X, XI, dan XII yaitu 70. Jika nilai peserta didik belum memenuhi KKM yang sudah ditetapkan sekolah, maka kedua subjek akan memberikan remidial untuk peserta didik. Jika dengan adanya remidial tetap masih ada nilai peserta didik yang belum mencapai KKM, maka kedua subjek akan memberikan tugas tambahan untuk peserta didik.

Kedua subjek mengungkapkan hal yang sama tentang penilaian. Kedua subjek menilai peserta didik sesuai dengan tuntutan dari kurikulum 2013 yaitu penilaian mencakup 3 aspek atau ranah (ranah kognitif atau pengetahuan, ranah afektif atau sikap dan ranah psikomotorik atau perilaku). Apabila terdapat peserta didik yang nilaianya berada dibawah kriteria ketuntasan minimal maka kedua subjek akan mengadakan kegiatan remidial untuk memperbaiki nilai peserta didik, dan jika masih terdapat peserta didik yang nilainya belum mencapai KKM setelah dilaksanakan kegiatan remidial maka kedua subjek akan memberikan tugas tambahan kepada peserta didik. Hasil dari penelitian ini sama dengan hasil dari penelitan Apriliyanti (2016) dalam PCK guru SMP pada materi Perbandingan. Hasil penelitian Apriliyanti menunjukkan bahwa subjek selalu memberikan remidiasi kepada peserta didik yang tidak mencapai batas KKM, entah dengan pemberian soal secara langsung di dalam kelas maupun dengan tugas-tugas yang diberikan oleh subjek untuk dikerjakan oleh peserta didik. Diperoleh hasil yang sama mengenai pengetahuan tentang penilaian antara guru perempuan dan guru laki-laki, keduanya sama-sama memberikan remidial dan tugas tambahan jika terdapat peserta didik yang nilainya kurang dari KKM.

\section{Komponen Pengetahuan Tentang Sumber Daya}

Kedua subjek menggunakan media yang sama saat mengajar, yaitu buku paket dan LKS yang disediakan oleh sekolahan. Kedua subjek juga sama-sama menggunakan alat peraga pada materimateri tertentu. Untuk subjek P menggunakan alat peraga pada materi dimensi 3, sedangkan untuk subjek L menggunakan alat peraga pada materi trigonometri dan statistika. Hal tersebut kedua subjek lakukan karena keterbatasan alat peraga yang dimiliki sekolah serta tidak mendukungnya kondisi peserta didik. Hal ini terbukti dari hasil wawancara kedua subjek dengan peneliti pada percakapan berikut:

Guru $P \quad$ : Paling ya kalau pas dimensi 3 pakai mbak.

Guru L : Trigonometri dan statistika.

Terdapat persamaan yang diungkapkan oleh subjek P dan subjek L berkaitan dengan sumber daya. Kedua subjek lebih sering menggunakan LKS dan buku paket yang telah disediakan oleh pihak 
sekolah sebagai media belajar dan sumber informasi. Sedangkan untuk alat peraga, keuda subjek juga sama-sama menggunakan alat peraga pada materi tertentu dikarenakan tidak semua materi dapat dijelaskan atau disampaikan dengan alat peraga. Hasil penelitian ini sama dengan hasil penelitian dari Apriliyanti (2016) dalam PCK guru SMP pada materi Perbandingan. Hasil penelitian Apriliyanti menunjukkan bahwa masing-masing subjek memiliki sumber materi yang berbeda, walaupun sebagian besar menggunakan LKS dan buku paket sebagai acuan. Diperoleh hasil yang sama mengenai sumber daya antara guru perempuan dan guru laki-laki, keduanya sama-sama menggunakan LKS dan buku paket saat pembelajaran.

\section{Komponen Pengetahuan Tentang Content}

Menurut kedua subjek, adanya kurikulum 2013 membuat perubahan materi yang harus diberikan untuk peserta didik. Materi yang ditetapkan pada kurikulum 2013 lebih banyak dan tidak runtut dibandingkan dengan KTSP. Hal ini terbukti pada hasil wawancara kedua subjek dengan peneliti pada percakapan berikut:

Materi matematika berubah-ubah sini, yang kelas X bisa diajarkan di kelas XII, Guru P : yang kelas XII bisa diajarkan di kelas X sekarang. Gak kayak dulu, enakan pakai KTSP dulu. Materinya sedikit dan urut. Sekarang satu semester itu to mbak setahun itu 10 bab.

Agak lupa saya mbak, untuk kemarin di LKS nya itu ada turunan. Tapi untuk yang

Guru L : ini gak ada, jadi saya agak bingung. Turunan itu diberikan atau gak pada semester ini.

Berkaitan dengan materi pembelajaran, subjek $\mathrm{P}$ terlihat sangat menguasai saat peneliti bertanya materi yang ditetapkan kurikulum 2013. Berbeda dengan subjek L yang kurang mengetahui urutan materi yang berlaku pada pembelajaran matematika kurikulum 2013. Kendala subjek P saat mengajar peserta didik yaitu pada soal-soal yang diberikan. Peserta didik kurang kreatif untuk mengerjakan berbagai soal, sehingga peserta didik kebingungan jika diberi bentuk soal yang berbeda pada materi yang sama. Sedangkan kendala yang dialami subjek L saat mengajar materi pembelajaran matematika yaitu hanya keramaian peserta didik yang terjadi dalam kelas.

Berbicara tentang content dari kedua subjek mengemukakan bahwa dengan adanya kurikulum 2013 ternyata membuat subjek merasa kesulitan, hal tersebut dikarenakan materi yang terdapat dalam kurikulum 2013 banyak yang tidak runtut, sehingga berdampak pula pada pemahaman peserta didik yang kurang terhadap materi pembelajaran matematika. Akan tetapi ketika peneliti mengajukan pertanyaan yang berkaitan dengan materi, subjek $\mathrm{P}$ terlihat sangat menguasai materi pembelajaran, berbeda dengan subjek L yang terlihat kurang menguasai materi pembelajaran. Hasil dari penelitian ini sama dengan hasil dari penelitan Apriliyanti (2016) dalam PCK guru SMP pada materi Perbandingan. Hasil penelitian Apriliyanti menunjukkan bahwa satu subjek tidak dapat menjelaskan secara spesifik mengenai materi lain yang berhubungan dengan materi perbandingan tetapi hanya menyatakan bahwa setiap materi dalam matematika memiliki hubungan erat yang tidak dapat dipisahkan satu dengan yang lainnya. Terdapat perbedaan antara guru perempuan dan guru laki-laki, 
guru perempuan lebih menguasai materi yang terdapat dalam kurikulum 2013 dibandingkan dengan guru laki-laki.

\section{Komponen Pengetahuan Tentang Tujuan}

Kedua subjek saat memulai pembelajaran terlebih dahulu menyampaikan tujuan pembelajaran yang harus dicapai peserta didik. Kedua subjek juga menyampaikan jika materi-materi prasyarat sangat membantu peserta didik untuk mencapai tujuan pada pembelajaran yang sedang berlangsung. Banyak materi pembelajaran matematika yang dapat diterapkan dalam kehidupan sehari-hari. Tetapi tidak semua materi pembelajaran matematika dapat diterapkan dalam kehidupan sehari-hari menurut kedua subjek. Hal ini terbukti pada hasil wawancara kedua subjek dengan peneliti pada percakapan berikut:

\section{Sebelum memulai pembelajaran biasanya saya sampaikan mbak. Tapi ya jarang- \\ Guru P : jarang saya smpaikan tujuannya [tertwa]. Soalnya kan satu materi belum tentu kalau sekali pertemuan dapat selesai mbak. Bisa diteruskan pada pertemuan selanjutnya kalau belum selesai. \\ Guru L : $\begin{aligned} & \text { Sebelum memulai pembel } \\ & \text { terlebih dahulu mbak. }\end{aligned}$}

Pengetahuan tentang tujuan menurut kedua subjek yang peneliti wawancara, dalam pelaksanaan kegiatan pembelajaran keduanya sama-sama menyampaikan tujuan pembelajaran terlebih dahulu. Hasil penelitian ini sama dengan hasil penelitian daari Windarto (2016) dalam PCK guru pada materi Aljabar kelas VII di SMP kecamatan Bringin. Hasil penelitian Windarto menunjukkan bahwa semua subjek memberitahukan tujuan pembelajaran di awal pembelajaran supaya peserta didik mengetahui tujuan pembelajaran Aljabar. Menurut kedua subjek penyampaian tujuan pembelajaran sangat berdampak terhadap keberhasilan belajar peserta didik karena dengan penyampaian tujuan pembelajaran ini peserta didik akan memahami bahwa pada saat itu mereka akan belajar materi apa. Diperoleh hasil yang sama mengenai pengetahuan tentang tujuan antara guru perempuan dan guru laki-laki, keduanya menyampaikan tujuan pembelajaran terlebih dahulu.

\section{KESIMPULAN}

Berdasarkan hasil penelitian dapat disimpulkan bahwa kedua guru sudah melaksanakan pembelajaran matematika dengan baik, akan tetapi belum dapat membuat antusias keaktifan peserta didik saat pembelajaran berlangsung. Kedua guru sudah menerapkan model-model pembelajaran yang ada untuk peserta didik. Dalam pembelajaran matematika, guru perempuan lebih aktif pada saat pelaksanaan pembelajaran dibandingkan dengan guru laki-laki. Dari sesi penilaian, kedua guru sudah melakukan penilaian sesuai dengan aspek penilaian kurikulum 2013. Kedua guru kurang dalam penggunaan alat peraga yang dapat digunakan saat pembelajaran matematika. Penguasaan materi pada kedua guru berbeda, guru perempuan lebih paham mengenai materi yang ada dalam kurikulum 2013. 


\section{REFERENSI}

Abi, Alfonsa Maria dkk. 2011. Deskripsi Pedagogical Content Knowledge Guru pada Bahasan tentang Pola Bilangan.

$\begin{array}{llll}\text { Anwar, } & \text { Yenny. } & 2010 . & \text { Pedagogical }\end{array}$ https://yennyanwar.blogspot.com/2010[20/3/2011]

Apriliyanti, Dita. 2016. Deskripsi Pedagogical Content Knowledge Guru SMP dalam Materi Perbandingan.

Arikunto, Suharsini. 2010. Prosedur Penelitian: Suatu Pendekatan Praktik. Jakarta: Rikena Cipta.

Chandra, Julius. 1983. Feminin dan Maskulin. Yogyakarta: Yayasan Kanisius.

Franyoto, Yuvita Sari dkk. 2011. Deskripsi Kompetensi Guru Menurut Pedagogical Content Knowledge pada Bahasan Tentang Himpunan.

http://www.hukumonline.com/pusatdata/downloadfile/lt594243f60618f/parent/lt594243926de09 (senin, 9 April 2018. Pukul 23.25 WIB)

Mahmud. 2011. Metode Penelitian Pendidikan. Bandung: Pustaka Setia.

Mampouw, Helti Lygia. 2011. Pedagogical content knowledge guru pada pembelajaran tentang luas gabungan di sekolah dasar.

Musfiqon. 2012. Metodologi Penelitian Pendidikan. Jakarta: Prestasi Pustaka.

Nugroho, Riant. Gender dan Strategi Pengarus-Utamaannya di Indonesia. Yogyakarta: Pustaka Pelajar.

Riduwan. 2009. Metode dan Teknik Menyusun Proposal Penelitaian. Bandung: ALFABETA.

Shulman, L. S. (1986). Those who understand: Knowledge growth in teaching. Educational Researcher, 15(2), 4-14.

Windarto, Agus. 2016. Deskripsi Pedagogical Content Knowledge Guru pada Materi Aljabar Kelas VII di SMP Kecamatan Bringin. 